\title{
Ecology of Birds and Insects in Organic and Conventional (In-Organic) Rice Ecosystem
}

\author{
G.K. Dinesh ${ }^{1 *}$, P.T. Ramesh ${ }^{1}$, N. Chitra ${ }^{2}$ and M.P. Sugumaran ${ }^{1}$ \\ ${ }^{1}$ Department of Environmental Sciences, ${ }^{2}$ Department of Agricultural Entomology, Tamil \\ Nadu Agricultural University, Coimbatore-641003, Tamil Nadu, India \\ *Corresponding author
}

\section{A B S T R A C T}

\section{Keywords}

Ecology, Birds, Insects,

Organic rice,

Conventional rice, Non-

organic, Population

count, Biodiversity, Rice

ecosystem, Wetland birds

Article Info

Accepted:

16 March 2018

Available Online:

10 April 2018
This Investigation was undertaken in the wetlands farm of Tamil Nadu Agricultural University, Coimbatore during Thaladi season to study the ecology of birds and insects in inorganic and organic rice ecosystem, with special reference to the species abundance, diversity, richness, evenness and similarity indices. This study revealed that organic cultivation supports bird diversity and beneficial insects. However, the bird menace during maturity stage is an issue to be managed in an ecofriendly way.

\section{Introduction}

Ecosystems on earth are unique components, where organisms interact within them and also with others, and that they are characteristic to that ecosystem. Agricultural ecosystems are unique man made ecosystem on earth that acts as a habitat for various living and non living organisms. It provides food and shelter to insects, birds, spiders, crabs, frogs and rodents.

Rice is a major food crop in India, grown in an area of 81 lakh hectares (Ministry of Agriculture, 2016) covering all agro-climatic regions of the country, from uphill to flooded (low land) and semi flooded ecosystems. Rice ecosystem is an important wetland ecosystem and a variety of flora and fauna are associated with paddy cultivation. Agricultural ornithology is the study of birds in relation to agriculture. It aims at obtaining scientific information on birds in relation to agriculture and using that information for their management (Ali, 1971).

\section{Materials and Methods}

The study was conducted in Thaladi season, (01 September 2016 to 17 January 2016. Organic rice field ( $0.91 \mathrm{ha})$ was located in "O" block (Survey number 380 and GPS location 
$\left.11^{\circ} 00^{\prime} 08.2^{\prime \prime} \mathrm{N}, 76^{\circ} 55^{\prime} 28.7^{\prime \prime} \mathrm{E}\right)$ of the wetlands. Inorganic field ( 0.89 ha) was located in " $K$ " block (Survey number 430 and GPS location $\left.11^{\circ} 00^{\prime} 09.8^{\prime \prime} \mathrm{N}, 76^{\circ} 55^{\prime} 32.2^{\prime \prime} \mathrm{E}\right)$ of Wetlands. The respective date of sowing for organic and inorganic rice was 07.09.2016 and 01.09.2016 in Thaladi season. The method of cultivation adopted was System of Rice Intensification (SRI).

The quantity of inorganic fertilizer received by inorganic field in Thaladi and was 150:50:50 $\mathrm{kg}$ of N: P: K respectively.

The inputs of the organic rice fields of Thaladi included enriched farm yard manure (EFYM) @ $750 \mathrm{~kg} \mathrm{ha}^{-1}, 100 \mathrm{~kg} \mathrm{ha}^{-1}$ of rock phosphate, $200 \mathrm{~kg} \mathrm{ha}^{-1}$ of neem cake, 3\% panchagavya spray and $12.5 \mathrm{t} \mathrm{ha}^{-1}$ of Farm yard manure (FYM).

\section{Species diversity estimation}

Species or alpha diversity of birds was quantified using Simpson's reciprocal diversity Index (SRDI) (Simpson, 1949) and Shannon-Wiener index (Shannon and Weaver, 1964).

\section{Simpson's index for species diversity}

Simpson's diversity Index is a measure of diversity which takes into account the number of species present, as well as the relative abundance of each species. It is calculated using the formula

$\mathrm{D}=\Sigma \mathrm{n}(\mathrm{n}-1) / \mathrm{N}(\mathrm{N}-1)$

Simpson reciprocal index $=1 / \mathrm{D}$

\section{Shannon-Wiener index for species diversity}

Shannon-Wiener index (H') was calculated using the formula,

$\mathrm{H}^{\prime}=-\Sigma \mathrm{Pi} \ln (\mathrm{Pi})$,

\section{Margalef index for species dominance}

Species dominance was calculated for the two sites using the Margalef index (Margalef, 1958) which is given as Margalef Index.

$\alpha=(\mathrm{S}-1) / \ln (\mathrm{N})$

\section{Pielou's index for species evenness}

Species evenness was calculated using the Pielou's Evenness Index (E1) (Pielou, 1966). As species richness and evenness increase, diversity also increases (Magurran, 1988). Pielou's Evenness Index,

$\mathrm{EI}=\mathrm{H}^{\prime} / \ln (\mathrm{S})$

Species diversity in two fields (beta diversity) estimation

Beta diversity is a measure of how different (or similar) ranges of habitats and their associated species comparison varies (Shweta and Rajmohana, 2016).

The most widely used index for assessment of Beta diversity is Jaccard Index (JI) (Jaccard, 1912; Gianni et al., 2011; Ricardo and Francisco, 2011) which is calculated using the equation,

$q($ for two sites $)=j /(a+b-j)$

All the diversity analyses were done using Microsoft Excel (2013), excel sheet calculator provided by (Klaus, 2013) and Species Diversity and Richness software by (Henderson and Seaby, 2001).

\section{Assessment of prey (insect) diversity at various stages}

The insect species were estimated by using a standard sweep net $(30 \times 60 \mathrm{~cm})$. The insects were collected in the rice fields at intervals of 
three days at one hour after the sunrise to 9 a.m. and from 3.00 p.m. to 6.30 p.m. twenty sweepings were made at random in five places of the field at random. The sweeps were made at ground vegetation above one feet height from the ground for collecting insects from crops. Collection of insects in both organic and inorganic rice fields were carried out on the same day itself.

The collected insects were curated and preserved as per Johnson and Triplehorn (2005) and was identified as per the taxonomic keys of Sheperd et al., (1992) and with reference collections of Insect Biosystematics laboratory, Department of Agricultural Entomology, TNAU, Coimbatore.

Diversity of insects prey species at different stages of rice were assessed by using Shannon Wiener index and Simpson reciprocal index, dominance of insects by Margalef index, Evenness by Pielou's index and beta diversity by Jaccard similarity index. All the analyses were done using Microsoft Excel (2013), PAST software (Hammer et al., 2001) and Species Diversity and Richness software by (Henderson and Seaby, 2001).

\section{Results and Discussion}

The study recorded a total of 26 species in inorganic rice ecosystem as compared to 25 species in organic rice ecosystem. However, with respect to number of birds, organic ecosystem recorded $29.69 \%$ higher bird population compared to inorganic system. Maturity stage attracted more birds than other crop stages in both organic and inorganic rice. Red Wattled Lapwing, Egret, White Browed Wagtail, Indian Pond Heron, Common Sandpiper were dominant in organic rice and Red Wattled Lapwing, Egret, Indian Pond Heron, Common Myna, Black Drongo were dominant in inorganic rice. Species diversity by Shannon Wiener index, Simpson reciprocal index was high in birds of organic rice ecosystem, when compared to inorganic rice ecosystem. In insects, diversity was high inorganic rice ecosystem. The species recorded in the organic and inorganic rice ecosystem were mentioned in table 1 and 2 for birds and insects respectively.

\section{Shannon Wiener diversity index}

Shannon Wiener index is the basic and fundamental indicator of species diversity and richness. In Shannon Wiener calculation, higher the value obtained, higher is the diversity. In inorganic rice, the diversity of birds in Thaladi ranged from 0.947 to 1.990 . An overall analysis revealed that the bird diversity was less in post-harvest and active tillering stage (Table 3). The diversity of insects was high in panicle initiation stage in both organic and inorganic rice ecosystem. Bakar and Khan (2016) also recorded maximum Margalef index value at tillering stage and active tillering stage. It is due to attraction of insects towards panicles.

\section{Simpson reciprocal diversity index}

Simpson's reciprocal index is a simple mathematical measure that characterizes species diversity in a community. More diversity of birds was occurred in nursery stage of organic and inorganic rice. Diversity of insects was higher in tillering stages of inorganic rice and panicle initiation stages of rice. The insects like sucking and sap feeding insects such as grasshopper, yellow stem borer and rice hispa were recorded high in the tillering stages (Table 4). This was due to increase in the canopy and insect may attract towards the new growing tillers. Similar results were also recorded by Wilby (2006) wherein the maximum Simpson diversity was recorded in tillering stage of rice. 


\begin{tabular}{|l|}
\hline \multicolumn{1}{|c|}{ Common name } \\
\hline Indian Pond Heron \\
\hline White Browed Wagtail \\
\hline Little Egret \\
\hline Darter \\
\hline Cattle Egret \\
\hline White Breasted Waterhen \\
\hline Purple Moorhen \\
\hline Bronze Winged Jacana \\
\hline Red Wattled Lapwing \\
\hline Grey Wagtail \\
\hline Blue Rock Pigeon \\
\hline House Crow \\
\hline Common Myna \\
\hline Black Drongo \\
\hline Black Kite \\
\hline Spotted Owlet \\
\hline Green Shank \\
\hline Indian Roller \\
\hline Common Sandpiper \\
\hline White Throated Kingfisher \\
\hline Brahminy Kite \\
\hline Blue Tailed Bee Eater \\
\hline Eurasian White Collared Dove \\
\hline White Throated Kingfisher \\
\hline Asian Open Bill Stork \\
\hline Spotted Munia \\
\hline Tricolored Munia \\
\hline Common Parakeet \\
\hline Peafowl \\
\hline Whimbrel \\
\hline
\end{tabular}

Table.1 List of birds recorded

\begin{tabular}{|c|c|c|}
\hline Scientific name & Family & Order \\
\hline Ardeola grayii (Sykes) 1832 & Ardeidae & Pelecaniformes \\
\hline Motacilla maderaspatensis (Gmelin) 1789 & Motacillidae & Passeriformes \\
\hline Egretta garzetta (Linnaeus) 1766 & Ardeidae & Pelecaniformes \\
\hline Plotus anhinga (Linnaeus) 1766 & Anhingidae & Suliformes \\
\hline Bubulcus ibis (Linnaeus) 1758 & Ardeidae & Pelecaniformes \\
\hline Amaurornis phoenicurus (Pennant) 1769 & Rallidae & Gruiformes \\
\hline Porphyrio poliocephalus (Latham) 1801 & Rallidae & Gruiformes \\
\hline Metopidius indicus (Latham) 1790 & Jacanidae & Charadriiformes \\
\hline Vanellus indicus (Boddaert) 1783 & Charadriidae & Charadriiformes \\
\hline Motacilla cinerea (Tunstall) 1771 & Motacillidae & Passeriformes \\
\hline Columba livia (Gmelin) 1789 & Columbidae & Columbiformes \\
\hline Corvus splendens (Vieillot) 1817 & Corvidae & Passeriformes \\
\hline Acridotheres tristis (Linnaeus) 1758 & sturnidae & Passeriformes \\
\hline Dicrurus macrocercus (Vieillot) 1817 & Dicruridae & Passeriformes \\
\hline Milvus migrans (Boddaert) 1783 & Accipitridae & Accipitriformes \\
\hline Athene brama (Temminck) 1821 & Strigidae & Strigiformes \\
\hline Tringa nebularia (Gunnerus) 1767 & Scolopacidae & Charadriiformes \\
\hline Coracias benghalensis (Linnaeus) 1758 & Coraciidae & Coraciiformes \\
\hline Acititis hypoleucos (Linnaeus) 1758 & Scolopacidae & Charadriiformes \\
\hline Halcyon smyrnensis (Linnaeus) 1758 & Alcedinidae & Coraciiformes \\
\hline Haliaster Indus (Boddaert) 1783 & Accipitridae & Accipitriformes \\
\hline Merops philippinus (Linnaeus) 1766 & Meropidae & Coraciiformes \\
\hline Streptopelia decaocto (Frivaldszky) 1838 & Columbidae & Columbiformes \\
\hline Halcyon smyrnensis (Linnaeus) 1758 & Alcedinidae & Coraciiformes \\
\hline Anastomus oscitans (Boddaert) 1783 & Ciconiidae & Ciconiiformes \\
\hline Lonchura punctulata (Linnaeus) 1758 & Estrildidae & Passeriformes \\
\hline Lonchura Malacca (Linnaeus) 1766 & Estrildidae & Passeriformes \\
\hline Psittacara holochlorus (Sclater) 1859 & Psittacoidae & Psittaciformes \\
\hline Pavo cristatus (Linnaeus) 1758 & Phasianidae & Galliformes \\
\hline Numenius phaeopus (Linnaeus) 1758 & Scolopacidae & Charadriiformes \\
\hline
\end{tabular}

\begin{tabular}{|l|}
\hline \multicolumn{1}{|c|}{ Common name } \\
\hline Dragon fly \\
\hline Yellow stem borer \\
\hline Brown plant hopper \\
\hline Green leafhopper \\
\hline Rice hispa \\
\hline Rice leaf folder \\
\hline Rice caseworm \\
\hline Swarming caterpillar \\
\hline Cutworm \\
\hline Grasshopper \\
\hline Damsel fly \\
\hline Ant \\
\hline Rice bugs \\
\hline Stink bugs \\
\hline
\end{tabular}

Table.2 List of insects recorded

\begin{tabular}{|l|c|c|}
\multicolumn{1}{|c|}{ Scientific name } & Order & Family \\
\hline Sympetrum flaveolum (Selys, 1854) & Odonata & Coenagrionidae \\
\hline Scirpophaga incertulas (Walker, 1863) & Lepidoptera & Crambidae \\
\hline Nilaparvata lugens (Stal, 1854) & Hemiptera & Delphacidae \\
\hline Nephotetix virescens (Distant, 1908) & Hemiptera & Cicadellidae \\
\hline Dicladispa armigera (Oliver) 1808 & Coleoptera & Chrysomelidae \\
\hline Cnaphalocrocis medinalis (Guenee, 1859) & Lepidoptera & Crambidae \\
\hline Nymphula depunctalis (Guenee) 1854 & Lepidoptera & Pyrallidae \\
\hline Spodoptera mauritia (Boisduval) 1833 & Lepidoptera & Noctuidae \\
\hline Spodoptera litura (Fabricius, 1775) & Lepidoptera & Noctuidae \\
\hline Atractomorpha lata (Mochulsky, 1866) & Orthoptera & Pyrgomorphidae \\
\hline Agriocnemis pygmaea (Rambur, 1842) & Odonata & Coenagrionidae \\
\hline Solenopsis geminate (Fabricius, 1804) & Hymenoptera & Formicidae \\
\hline Leptocorisa oratoria (Fabricius, 1764) & Hemiptera & Alydidae \\
\hline Nezara viridula (Linnaeus, 1758) & Hemiptera & Pentatomidae \\
\hline
\end{tabular}


Table.3 Shannon Wiener diversity index

\begin{tabular}{|c|c|c|c|c|}
\hline \multirow{2}{*}{ Stages of rice } & \multicolumn{2}{|c|}{ Birds } & \multicolumn{2}{c|}{ Insects } \\
\hline Inorganic & Organic & Inorganic & Organic \\
\hline Nursery & 1.990 & 1.713 & 1.321 & 1.082 \\
\hline Transplanted & 1.823 & 1.642 & 1.376 & 1.079 \\
\hline Tillering & 0.947 & 1.556 & 1.846 & 1.073 \\
\hline Active tillering & 1.282 & 1.567 & 1.151 & 1.798 \\
\hline Panicle Initiation & 1.541 & 1.608 & 1.938 & 1.870 \\
\hline Maturity & 1.845 & 1.912 & 1.832 & 1.717 \\
\hline Post harvest & 1.008 & 0.800 & NA & NA \\
\hline
\end{tabular}

\begin{tabular}{|c|c|c|c|c|}
\hline \multirow{2}{*}{$\begin{array}{c}\text { Table.4 Simpson reciprocal index for birds in rice ecosystem } \\
\text { Stages of rice }\end{array}$} & \multicolumn{3}{|c|}{ Birds } & \multicolumn{2}{|c|}{ Insects } \\
\hline & Inorganic & Organic & Inorganic & Organic \\
\hline Nursery & 5.571 & 3.845 & 5.600 & 4.000 \\
\hline Transplanted & 3.531 & 4.062 & 5.056 & 4.200 \\
\hline Tillering & 1.750 & 3.134 & 8.053 & 3.391 \\
\hline Active tillering & 2.323 & 3.332 & 1.940 & 4.612 \\
\hline Panicle Initiation & 4.005 & 5.150 & 7.101 & 7.373 \\
\hline Maturity & 5.121 & 5.741 & 5.637 & 5.563 \\
\hline Post harvest & 2.260 & 2.030 & NA & NA \\
\hline
\end{tabular}

\begin{tabular}{|c|c|c|c|c|}
\hline \multirow{2}{*}{ Table.5 Margalef index for birds in rice ecosystem } \\
\hline Stages of rice & \multicolumn{3}{|c|}{ Birds } & \multicolumn{2}{c|}{ Insects } \\
\hline Inorganic & Organic & Inorganic & Organic \\
\hline Nursery & 3.253 & 2.405 & 1.443 & 0.962 \\
\hline Transplanted & 2.868 & 1.865 & 1.137 & 1.028 \\
\hline Tillering & 1.491 & 2.191 & 2.076 & 0.780 \\
\hline Active tillering & 1.438 & 1.889 & 2.184 & 2.156 \\
\hline Panicle Initiation & 1.300 & 0.831 & 2.199 & 1.764 \\
\hline Maturity & 2.580 & 1.656 & 1.967 & 1.123 \\
\hline Post harvest & 0.724 & 0.539 & NA & NA \\
\hline
\end{tabular}

\begin{tabular}{|l|c|c|c|c|}
\hline \multirow{2}{*}{ Table.6 Pielou's Evenness index for birds in rice ecosystem } \\
\hline & \multicolumn{3}{|c|}{ Birds } & \multicolumn{2}{c|}{ Insects } \\
\hline Nurges of rice & Inorganic & Organic & Inorganic & Organic \\
\hline Transplanted & 0.776 & 0.689 & 0.953 & 0.875 \\
\hline Tillering & 0.658 & 0.685 & 0.993 & 0.941 \\
\hline Active tillering & 0.487 & 0.649 & 0.949 & 0.918 \\
\hline Panicle Initiation & 0.583 & 0.631 & 0.524 & 0.568 \\
\hline Maturity & 0.792 & 0.999 & 0.882 & 0.822 \\
\hline Post harvest & 0.665 & 0.797 & 0.796 & 0.870 \\
\hline
\end{tabular}




\begin{tabular}{|c|cc|c|c|}
\multicolumn{2}{|c|}{ Table.7 Jaccard index of similarity coefficient for birds in organic and inorganic rice } \\
ecosystem \\
\hline Stages of rice & \multicolumn{3}{|c|}{$\begin{array}{c}\text { Birds } \\
\text { Insects }\end{array}$} \\
\cline { 2 - 5 } & $\begin{array}{c}\text { Jaccard index } \\
\text { value }\end{array}$ & $\begin{array}{c}\text { Similarity } \\
\text { percentage }\end{array}$ & $\begin{array}{c}\text { Jaccard index } \\
\text { value }\end{array}$ & $\begin{array}{c}\text { Similarity } \\
\text { percentage }\end{array}$ \\
\hline Nursery & 0.316 & 31.57 & 0.750 & 75.000 \\
\hline Transplanted & 0.500 & 50.00 & 0.400 & 40.000 \\
\hline Tillering & 0.286 & 28.57 & 0.250 & 25.000 \\
\hline Active tillering & 0.500 & 50.00 & 0.583 & 58.333 \\
\hline Panicle & 0.333 & 33.33 & 0.600 & 60.000 \\
\hline Initiation & & & & 60.000 \\
\hline Maturity & 0.688 & 68.75 & 0.600 & NA \\
\hline Post harvest & 0.750 & 75.00 & NA & \\
\hline
\end{tabular}

Plates

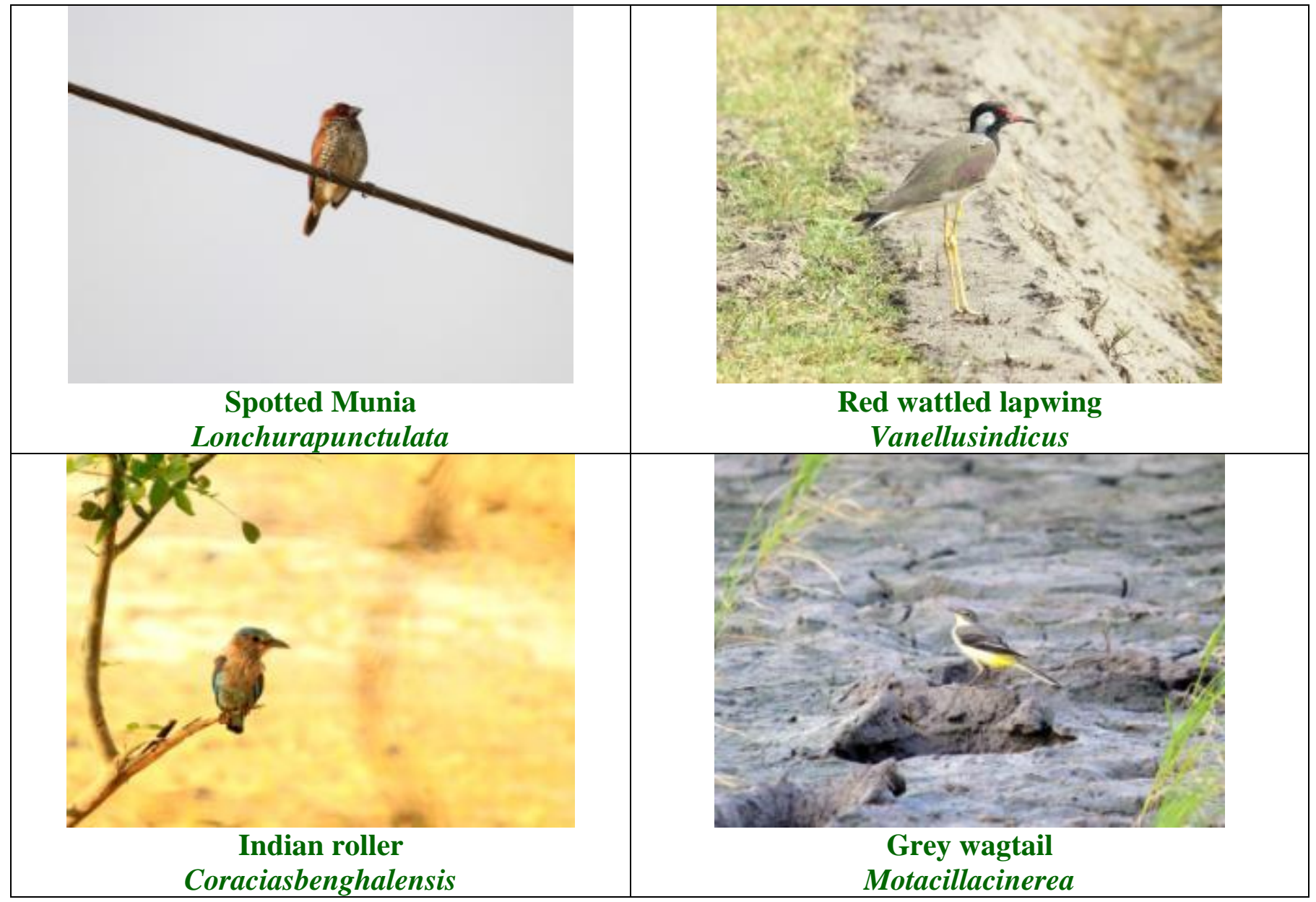




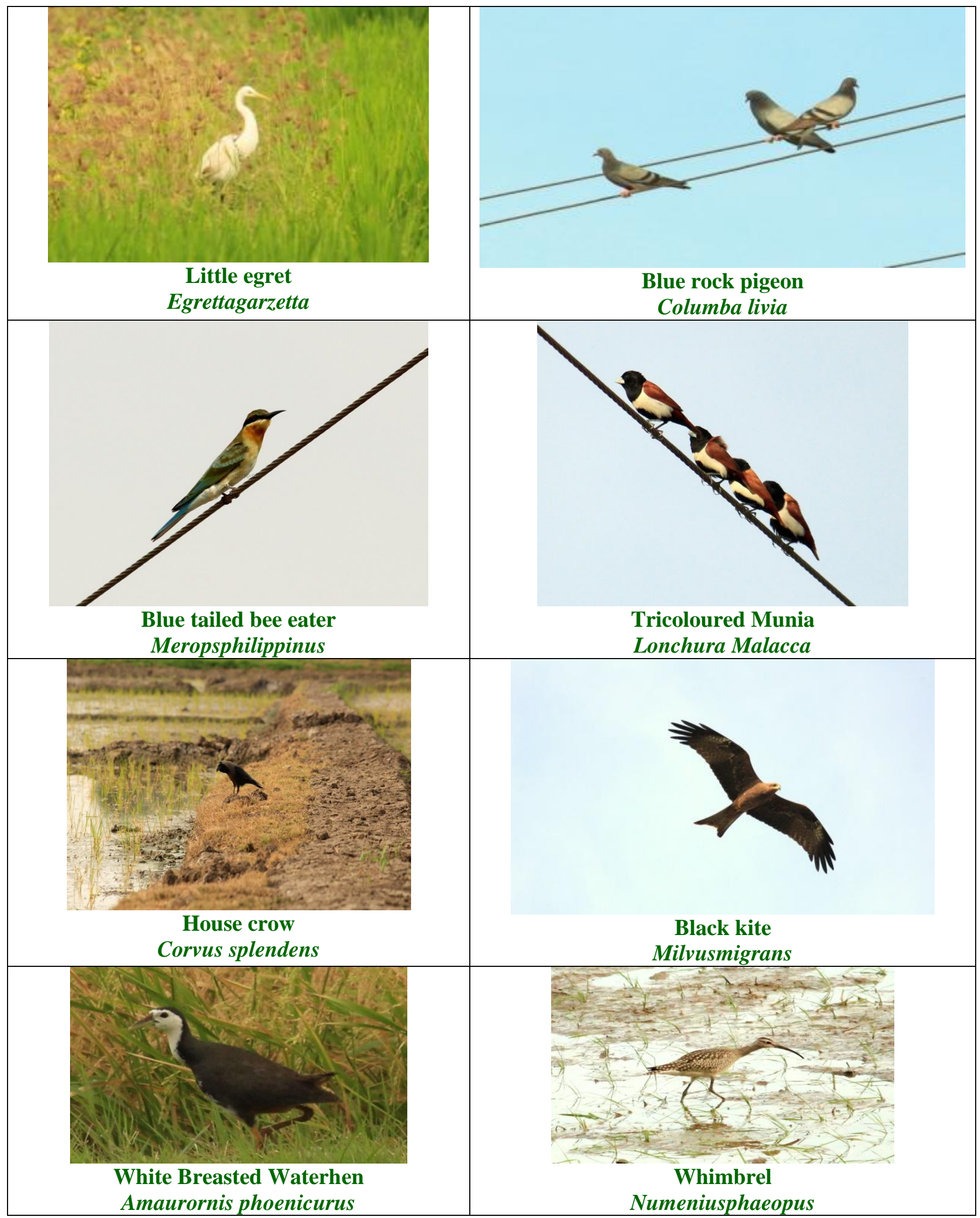



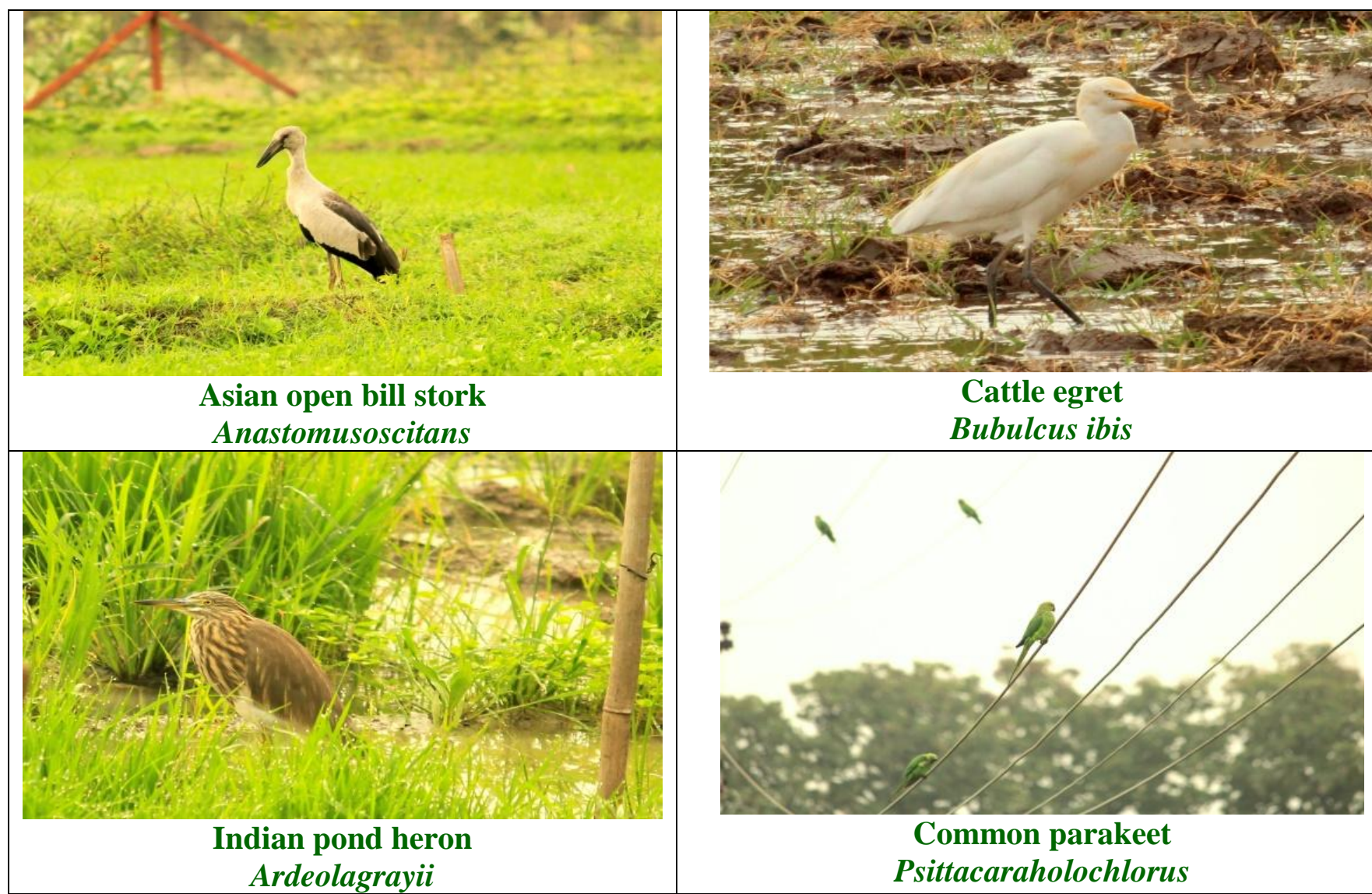

Cattle egret

Bubulcus ibis

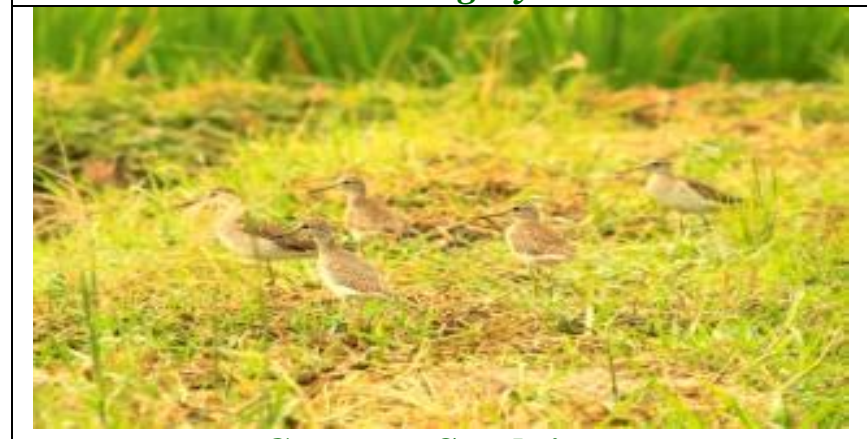

Common Sandpiper Acititishypoleucos

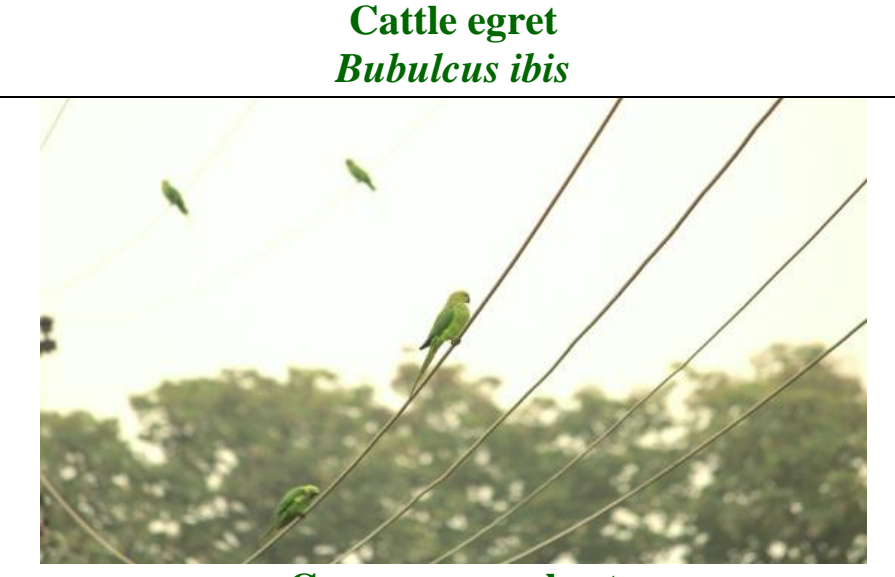

Common parakeet Psittacaraholochlorus

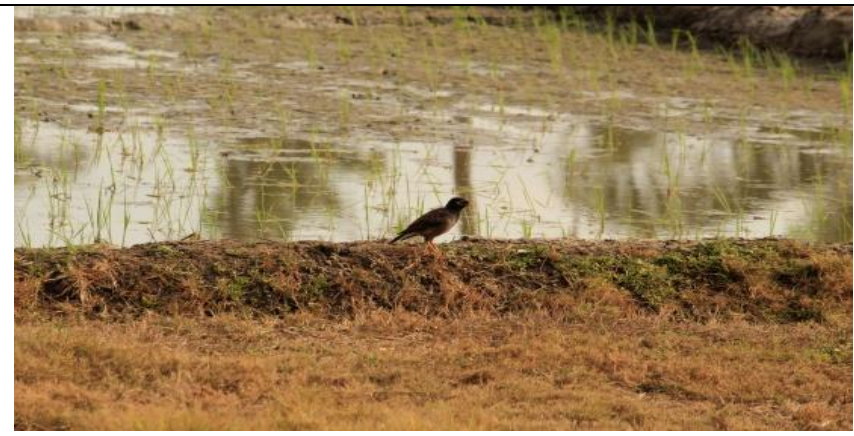

Common Myna Acridotheres tristis

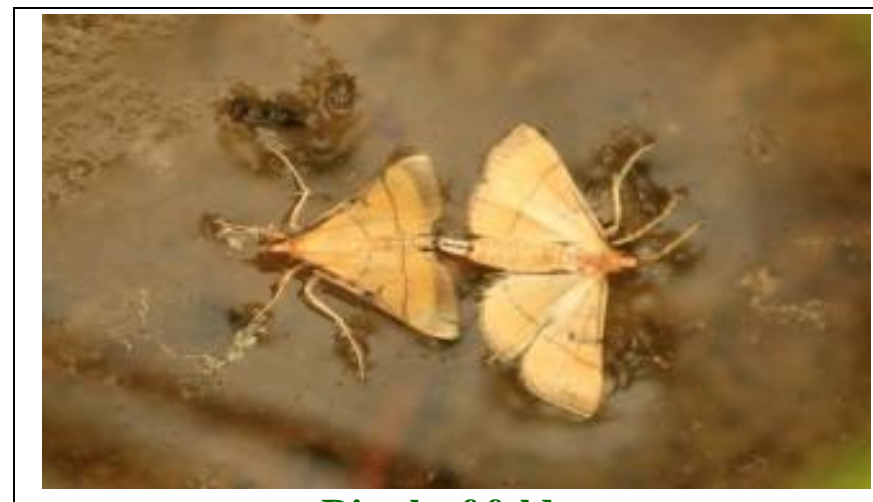

Rice leaf folder

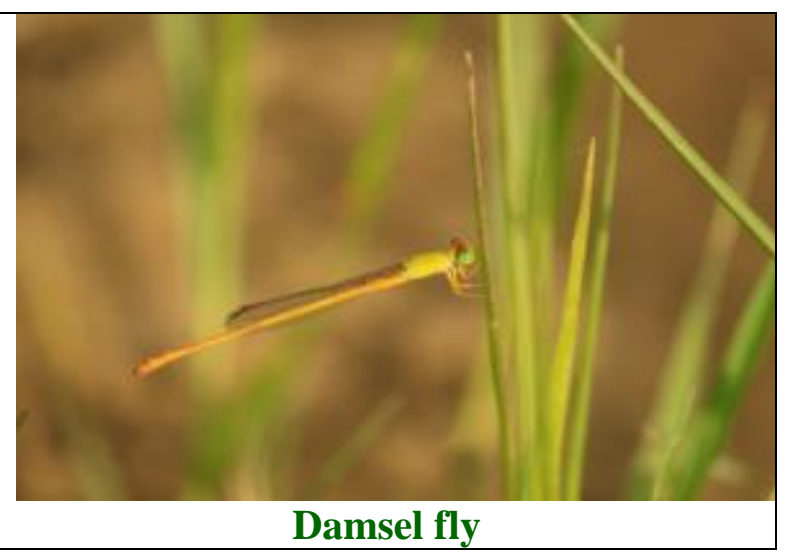




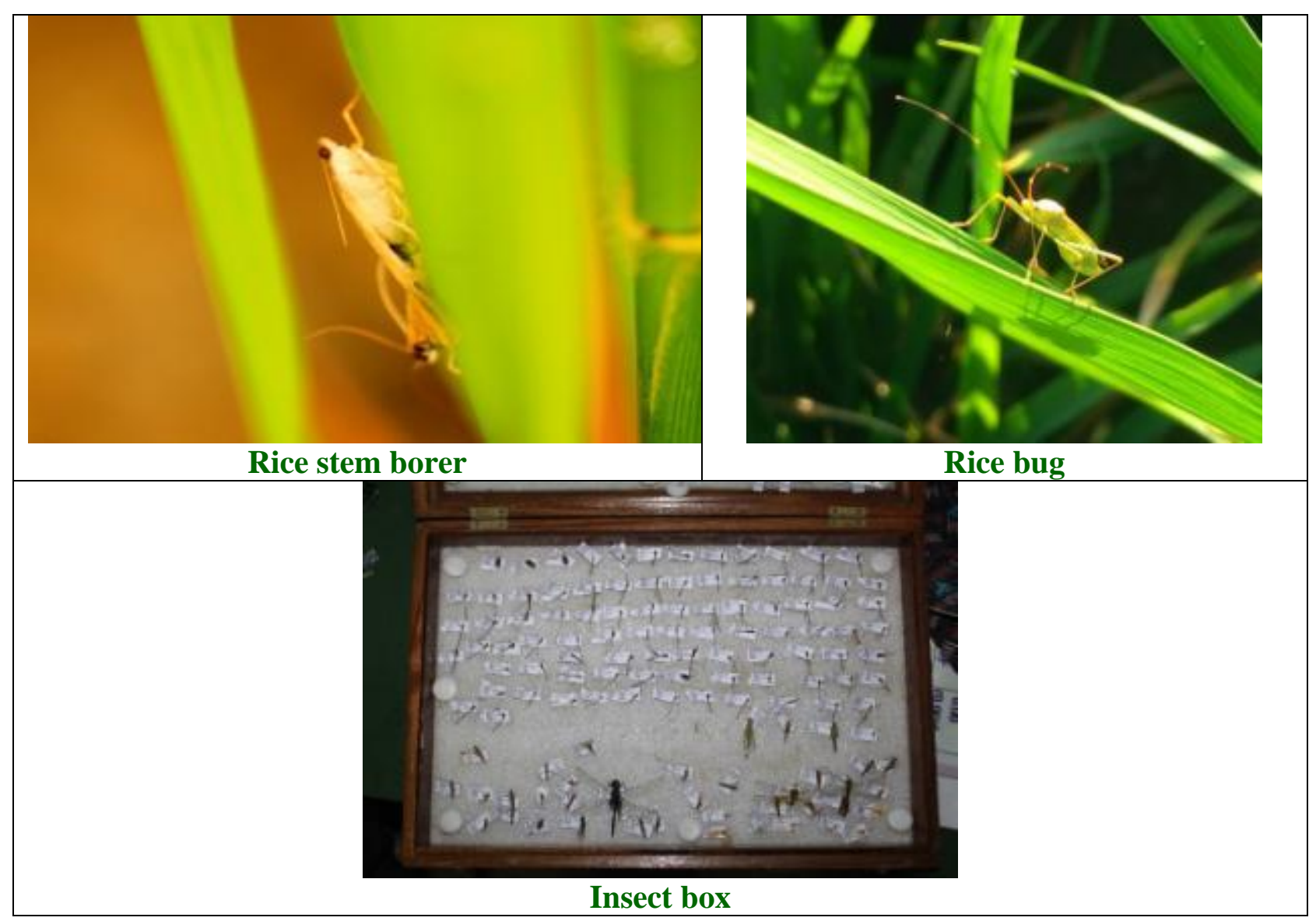

\section{Margalef index}

Species richness was high in organic rice field compared to inorganic rice. The nursery stages of inorganic rice recorded highest species richness, which however decreased in the later stages and finally increasing in the maturity stage.

The sparse count recorded on birds such as Brahminy Kite, Bronze Winged Jacana, Open Billed Stork, and Whimbrel has resulted in lesser Margalef Index values.

The Margalef index for species richness, revealed that the highest species richness was in tillering stage of organic rice and panicle initiation stage of inorganic rice (Table 5). Bakar and Khan (2016) also recorded maximum Margalef index value at tillering stage and active tillering stage.

\section{Pielou's evenness index}

Pielou's evenness index is the measure of evenness of the organisms. From the results, birds has maximum evenness index occurred in panicle initiation stage in organic rice of Thaladi season (0.999). Insects have high evenness in transplanted stage of both organic and inorganic rice ecosystem (Table 6).

\section{Jaccard index of similarity coefficient}

Jaccard index is the measure of similarity between two ecosystems. From the results of Jaccard index, it was observed that the similarity coefficient between organic and inorganic rice ranged from 28.57 to $75 \%$ for Thaladi (Table 7). Highest similarity of species $(75 \%)$ was recorded in post-harvest stage, where in little egret, blue rock pigeon and black drongo were the common bird 
species in both inorganic and organic fields. This was followed by maturity stage $(68.75 \%)$. Lowest similarity was observed in tillering stage $(28.57 \%)$, followed by nursery stage $(31.57 \%)$. Similar results of highest evenness were recorded in transplanting (seedling) stage of rice by Bakar and Khan (2016). This is due to the even occurrence of insects in the rice fields.

\section{Acknowledgement}

I like to acknowledge the farm manager Wetlands, and Department of Organic and Sustainable Agriculture, Tamil Nadu Agricultural University, Coimbatore for providing the field for this study and Department of Environmental Sciences for providing the opportunity to do this research.

\section{References}

Ali, S., 1971. Ornithology in India; Its past, present and future. Indian National Science Academy, 37: 99-113

Bakar, M. A. and M.H. Khan. 2016. Diversity of Insect Pests and Natural Enemies As Influenced By Growth Stages and Pest Management Practices in Rice. Bangladesh journal of Agricultural Research, 41(3):461-470.

Gianni, Q.H., J.C. Francisco and C.F.M. Andivan. 2011. Species diversity of myrmecofauna and araneofauna associated with agroecosystem and forest fragments and their interaction with Carabidae and Staphylinidae. Florida Entomologist, 94(1):500-509.

Hammer, O., D.A.T. Harper and P.D. Ryan. 2001. PAST: Paleontological statistics software package for education and data analysis. Palaeontologia Electronica, 4(1):1-9.

Henderson, P. A. and R.M.H. Seaby. 2001. Species diversity and richness 2.65 software package, United Kingdom: Pisces Conservation Ltd.

Jaccard, P. 1912. The Distribution of the Flora in the Alpine Zone. The Phytologist, 11(2): 37-50.

Johnson, N. and C. Triplehorn. 2005. Borror's and Delong's Introduction to the study of Insects. Thompsons - Brooks/Cole. California. 272 pp.

Klaus, G., 2013. BPMSG Diversity Calculator - Excel. [Online] Available at: http://bpmsg.com/bpmsg-diversitycalculator-excel/[Accessed 2611 2016].

Magurran, A.E. 1998. Ecological diversity and its measurements. Princeton university press. P. 192. Retrived from: press.printceton.edultitles $\backslash 4238$.html.

Margalef, R., 1958. Information theory in ecology. General Systems, 3: 36-71.

Ministry of Agriculture, Government of India. 2016. Rabi Crops Sowing Crosses 81 Lakh Hactare. [Online] Available at: http://pib.nic.in/newsite/printrelease.asp $\mathrm{x}$ ?relid $=153280$ [Accessed 18 March 2017].

Pielou, E. C. 1966. The Measurement of Diversity in Different Types of biological collections. Journal of theoretical biology, 13(1): 131-144.

Ricardo, J. P. and J.P.F. Francisco, J. P. F., 2011. Diversity and community structure of opiinae (Hymenoptera: Braconidae) in the forest estate of Artikutza (Spain). Florida Entomologist, 94(1):472-479.

Shannon, C. E. and W. Weaver. 1964. The Mathematical theory of communication. The University of Illinois Press. Urbana. 392pp.

Shepard, B. M., A.T. Barrion, and J.A. Litsinger. 1992. Friends of the rice farmer-Helpful insects, spiders and pathogens. International Rice Research Institute (IRRI). Philippines. 282pp.

Shweta, M. and K. Rajmohana. 2016. Egg parasitoids from the subfamily 
Scelioninae

Platygastridae ecosystems across varied elevational ranges in Southern India. Journal of Threatened Taxa, 8(6):8898-8904

Simpson, E. H., 1949. Measurement of Diversity. Nature, 163(1): 688.
Wilby, A. 2006. Arthropod Diversity and Community Structure in Relation to Land Use in the Mekong Delta, Vietnam. Ecosystems, 9(1), pp. 538549.

\section{How to cite this article:}

Dinesh, G.K., P.T. Ramesh, N. Chitra and Sugumaran, M.P. 2018. Ecology of Birds and Insects in Organic and Conventional (In-Organic) Rice Ecosystem. Int.J.Curr.Microbiol.App.Sci. 7(04): 1769-1779. doi: https://doi.org/10.20546/ijcmas.2018.704.201 